Gut, 1962, 3, 264

\title{
Studies on the stability of vitamin A in the stomach and small intestine
}

\author{
OLIVER FITZGERALD, JAMES J. FENNELLY, AND \\ DANIEL J. HINGERTY \\ From the Biochemistry Laboratories, Merville, University College, and \\ St. Vincent's Hospital, Dublin
}

EDITORIAL SYNOPSIS The instability of vitamin A alcohol relative to vitamin A acetate has been studied in vivo and in vitro.

Vitamin A alcohol is more unstable than vitamin A acetate in human gastric and duodenal juice and in rats' stomachs and intestines and is more marked at lower $p \mathrm{H}$ levels and in rats' stomachs.

Alpha tocopherol improved the absorption curve of vitamin A alcohol in man by protecting it in gastric and duodenal juice. This protective effect could not be demonstrated in the rat.

An advantage of the vitamin $A$ absorption test is that differential intestinal absorption can be tested by the use of vitamin $A$ alcohol and vitamin A acetate. Vitamin A acetate is poorly absorbed in all types of malabsorption, whereas vitamin A alcohol is well absorbed in malabsorption due to maldigestion, i.e., when pancreatic juice is deficient in function and emulsification. The pattern of absorption in over 100 cases on which these absorption tests were carried out in the past five years (FitzGerald, Fennelly, and Hingerty, 1961, 1962) is as follows:-

\begin{tabular}{lll} 
& $\begin{array}{l}\text { VITAMIN A ABSORPTION } \\
(250,000 \text { i.u. orally }) \\
\text { Vitamin } A \\
\text { Acetate }\end{array}$ & $\begin{array}{l}\text { Vitamin } A \\
\text { Alcohol }\end{array}$ \\
\hline $\begin{array}{l}\text { Normal } \\
\text { Coeliac disease } \\
\text { Pancreatic malabsorption }\end{array}$ & $\begin{array}{l}\text { Normal } \\
\text { Reduced } \\
\text { Reduced }\end{array}$ & $\begin{array}{l}\text { Normal } \\
\text { Reduced } \\
\text { Normal }\end{array}$
\end{tabular}

The normal person shows a rise in serum vitamin A concentration to over 800 i.u. $\%$. Occasionally, however, absorption curves after the ingestion of vitamin $\mathrm{A}$ alcohol are poor in relation to those of vitamin $\mathbf{A}$ acetate. This paradoxical situation is probably due to the greater instability of vitamin A alcohol.

Hopkins (1906) noted rapid destruction of biological activity of fatty substances when they are heated and exposed to air and later McCollum, Simmonds, Becker, and Shipley (1922) used the instability of vitamin $\mathbf{A}$ as a means of identification. A number of authors noted the instability of vitamin $A$ in studies of liver content in subjects after dosage of vitamin A with and without tocopherol. Tocopherol increased the liver storage of vitamin $A$ and carotene. Vitamin A alcohol is unstable, particularly if exposed to oxygen and $\mathrm{HCl}$ (Davies and Moore, 1941 ; Harris, Kaley, and Hickman, 1944; Hickman, Harris, and Woodside, 1942; Moore, 1957).

Our experiments have dealt with the instability under varying conditions of vitamin $\mathbf{A}$ in human gastric and duodenal juice and in rats' stomachs and intestines.

MATERIALS AND METHODS

EXPERIMENT I Studies of stability in vitro were carried out by the incubation of both preparations $(25,000$ i.u.) separately with human gastric and duodenal juice $(10 \mathrm{ml}$.) of varying $p \mathrm{H}$ at $37^{\circ} \mathrm{C}$. Breakdown was followed at two, four, eight, and 24 hours by estimating vitamin A, using a modification of the method of Kimble (1939), in which $0.5 \mathrm{ml}$. of the mixture was extracted with $5 \mathrm{ml}$. absolute alcohol and $5 \mathrm{ml}$. petroleum ether; $0.5 \mathrm{ml}$. of the petroleum ether layer was dried in a stream of nitrogen and dissolved in $0.5 \mathrm{ml}$. chloroform, then $2 \mathrm{ml}$. antimony trichloride solution was added and the blue colour read immediately in a Unicam spectrophotometer at $620 \mathrm{~m} \mu$. Tocopherol, when added, was prepared as a solution of alpha-tocopherol acetate, $1 \mathrm{ml}$. containing $50 \mathrm{mg}$.

EXPERIMENT II Wistar strain rats weighing 200 to $250 \mathrm{~g}$. were used for experiments in vivo. They were kept fasting for 20 to 24 hours. The stomachs of the anaesthetized animals were isolated and also $2 \mathrm{~cm}$. of small intestine, 
just distal to the pylorus. The circulation was not deliberately cut off though some damage was unavoidable. Then $0.3 \mathrm{ml}$. and $0.1 \mathrm{ml}$. of the vitamin A solution containing 25,000 i.u. and 8,333 i.u. were injected into the stomach and intestine respectively. Tocopherol acetate in amounts from 2.5 to $5 \mathrm{mg}$. was added to the vitamin $A$ preparation to estimate protective action. Two hours later the stomach and intestine were excised and extracted with $5 \mathrm{ml}$. absolute alcohol and $50 \mathrm{ml}$. petroleum ether. At the same time $\mathbf{0} \cdot 1 \mathrm{ml}$. of the original vitamin A preparation used was similarly extracted. Vitamin A was estimated as described in the first experiment.

EXPERIMENT III Over the past six years over 100 vitamin A absorption tests have been carried out in studies of the absorptive capacity of various patients. As already pointed out, anomalous curves were found in five of these in whom we checked the effect of administering alpha-tocopherol with vitamin $\mathbf{A}$ alcohol in a repeat of the test, leaving an interval of some days between tests.

\section{RESULTS}

Table I shows the breakdown of vitamin A acetate and alcohol respectively in gastric and duodenal juice at varying $p \mathbf{H}$. Vitamin $\mathrm{A}$ acetate appears to be quite stable when incubated with duodenal juice when the $p H$ is over 3.8 . In one case the duodenal juice was $3.8 \mathrm{pH}$.; in this case much more breakdown occurred. At lower $p \mathrm{H}$ levels the breakdown was even more marked. One reading $20 \%$ and $9 \%$ appears so much out of line as to be a probable experimental error so it is excluded from the mean figures. Vitamin A alcohol is more unstable at all pH levels, particularly at the more acid levels. Breakdown is fairly marked in the first four hours but most of it occurs between four and 24 hours.

Table II shows quite clearly the protective effect of alpha-tocopherol on vitamin A alcohol. Protection is given at all $p H$ levels. The amount remaining after two, four, and 24 hours' incubation with gastric juice compares well with that of vitamin A acetate remaining after similar intervals. The longterm protective effect of tocopherol in duodenal juice is also evident.

The results of experiments in vivo set out in Table III confirm the instability of vitamin $\mathbf{A}$ alcohol in
TABLE II

PROTECTION GIVEN TO VITAMIN A ALCOHOL BY TOCOPHEROL IN HUMAN GASTRIC AND DUODENAL JUICE

\begin{tabular}{lrcc} 
Juice & 2 Hours $^{1}$ & 4 Hours & 24 Hours \\
\hline Gastric (6 tests) $(p$ H 1.45 to 2.1) & 100 & 100 & 78.3 \\
Duodenal (6 tests) $(p$ H 3.8 to 7.0) & 89 & 77 & 61
\end{tabular}

'Percentage of initial concentration remaining at two, four, and 24 hours.

both rats' stomachs and intestines, probably more in the former. Vitamin $\mathbf{A}$ acetate is relatively much more stable. Efforts to demonstrate vitamin $\mathbf{A}$ alcohol protection by tocopherol during experiments in vivo on rats' stomachs and intestines were not successful and increased breakdown of the vitamin was seen in many experiments.

Table IV shows the improvement in the vitamin $A$ alcohol absorption in man after the test had been repeated with administration of alpha tocopherol to prevent breakdown. It appears that 100 to $200 \mathrm{mg}$. is the optimum dose of tocopherol.

\section{TABLE III}

BREAKDOWN OF VITAMIN A ACETATE AND VITAMIN A ALCOHOL IN RATS' STOMACHS AND INTESTINES AND EFFECT OF ADDED TOCOPHEROL

\begin{tabular}{|c|c|c|c|c|c|}
\hline \multicolumn{2}{|c|}{$\begin{array}{l}\text { Vitamin A Acetate } \\
(9 \text { Rats })\end{array}$} & \multicolumn{2}{|c|}{$\begin{array}{l}\text { Vitamin A Alcohol } \\
(17 \text { Rats })\end{array}$} & \multicolumn{2}{|c|}{$\begin{array}{l}\text { Vitamin A Alcohol } \\
(19 \text { Rats })+\text { Tocopherol }\end{array}$} \\
\hline Stomach & Intestine & Stomach & Intestine & Stomach & Intestine \\
\hline 99 & 93 & 64 & 78 & 44 & 53 \\
\hline
\end{tabular}

'Percentage of initial concentration remaining after two hours.

\section{DISCUSSION}

Vitamin A is broken down in two sites in the alimentary tract, the stomach and the intestine, but is more marked in the stomach than in the intestine (Tables I and III). The instability is due to oxidation of the vitamin in the stomach and small intestine. The increased breakdown with increased acidity is well

TABLE I

BREAKDOWN OF VITAMIN A ACETATE AND ALCOHOL IN HUMAN GASTRIC AND DUODENAL JUICE DURING INCUBATION AT $37^{\circ} \mathrm{C}$.

\begin{tabular}{|c|c|c|c|c|c|}
\hline Preparation & Juice & 2 Hours $^{1}$ & 4 Hours & 8 Hours & 24 Hours \\
\hline $\begin{array}{l}\text { Vitamin } \mathbf{A} \text { acetate } \\
\text { Vitamin } \mathbf{A} \text { acetate } \\
\text { Vitamin } \mathbf{A} \text { alcohol } \\
\text { Vitamin } \mathbf{A} \text { alcohol }\end{array}$ & $\begin{array}{l}\text { Gastric }(5)^{2} p H 1.45 \text { to } 2.1 \\
\text { Duodenal (5) pH } 3.8 \text { to } 7.0 \\
\text { Gastric (12) pH } 1.45 \text { to } 2.1 \\
\text { Duodenal (12) pH } 3.8 \text { to } 7.0\end{array}$ & $\begin{array}{r}71 \\
100 \\
72 \\
-\end{array}$ & $\begin{array}{l}66 \cdot 5 \\
92 \cdot 5 \\
52 \\
74\end{array}$ & $\begin{array}{l}\overline{96} \\
41 \\
63\end{array}$ & $\begin{array}{l}33 \cdot 5 \\
85 \cdot 4 \\
18 \\
24\end{array}$ \\
\hline
\end{tabular}

${ }^{1}$ Percentage of initial vitamin A concentration remaining at various intervals.

${ }^{2}$ No. of tests in breakets. 
TABLE IV

POST-ABSORPTION LEVELS IN FIVE SUBJECTS SHOWING PARADOXICAL CURVES AND EFFECT OF TOCOPHEROL

\begin{tabular}{|c|c|c|c|c|}
\hline No. & Description & $\begin{array}{l}\text { Acetate } \\
\text { (i.u./100 ml. } \\
\text { serum) }\end{array}$ & Alcohol & $\begin{array}{l}\text { Tocopherol plus } \\
\text { Vitamin A Alcohol }\end{array}$ \\
\hline 1 & Normal subject & 1,000 & 755 & $1,200(100 \mathrm{mg} .)^{1}$ \\
\hline 2 & Normal subject & - & 320 & $\begin{array}{l}731 \text { (100 mg.) } \\
566 \text { (500 mg.) } \\
509 \text { (1,000 mg.) }\end{array}$ \\
\hline 3 & Mucoviscidosis & 500 & 300 & 500 (100 mg.) \\
\hline 4 & Chronic uraemia & 1,600 & 1,000 & 1,000 (100 mg.) \\
\hline 5 & $\begin{array}{l}\text { Chronic uraemia } \\
\text { (1957) } \\
\text { (1959) }\end{array}$ & $\begin{array}{l}3,300 \\
2,200\end{array}$ & $\begin{array}{l}1.300 \\
1,100\end{array}$ & $\begin{array}{l}1,750 \text { (200 mg.) } \\
2,275 \text { (200 mg.) } \\
2,300 \text { (200 mg.) }\end{array}$ \\
\hline
\end{tabular}

${ }^{1}$ Tocopherol was given on the evening before and on the morning of the test in the amounts stated in brackets.

shown in Table I. In these experiments vitamin A acetate was comparatively stable. Tocopherol provides good protection during experiments in vitro in gastric and duodenal juice and apparently in vivo in human subjects (Table IV).

If we consider the possible degree of breakdown of vitamin A alcohol it is surprising that in almost all normal human subjects equal absorption curves are seen after the ingestion of vitamin $A$ acetate and vitamin $\mathrm{A}$ alcohol. The excessive breakdown of vitamin A alcohol seen in a few cases would suggest the use of the more stable acetate as a measure of absorptive capacity. The lesser stability of the vitamin $\mathbf{A}$ alcohol under certain conditions might obscure that difference in absorption between acetate and alcohol seen in patients with pancreatogenous steatorrhoea. The demonstration that serum levels of a patient are lower after vitamin A acetate than after the alcohol should always suggest pancreatic maldigestion. The opposite type of curve (where the alcohol is very poorly absorbed) might suggest that it has been broken down, unless the ester figure is also low, when a malabsorption defect would be the more reasonable explanation.

The apparent absence of a significant effect of tocopherol in protecting the vitamin A alcohol in the rat may have been due to an excess of tocopherol, or possibly to interference by the tocopherol in the procedure for determination of vitamin $\mathrm{A}$.

We are grateful to Roche Products Ltd. for supplies of vitamin $A$ and tocopherol used in these experiments. We are obliged to Professor E. J. Conway, F.R.S., for hospitality in carrying out these experiments at the Biochemical Laboratories, University College, Dublin, and to the Medical Research Council of Ireland for a grant-in-aid to one of us (J.J.F.) and for general financial assistance.

\section{REFERENCES}

Davies, A. W., and Moore, T. (1941). Interaction of vitamins A and E. Nature (Lond.), 147, 794-796.

FitzGerald, O., Fennelly, J. J., and Hingerty, D. J. (1961). Serum studies in man after administration of vitamin $\mathbf{A}$ acetate and vitamin A alcohol. (1) In normal subjects. Gut, 2, 263-266.

,--1 (1962). Serum studies in man after administration of vitamin $A$ acetate and vitamin $A$ alcohol. (2) Studies on subjects suffering from disturbances of absorption and digestion. Gut (In press).

Harris, P. L., Kaley, M. W., and Hickman, K. C. D. (1944). Covitamin studies. II. The sparing action of natural tocopherol concentrates on carotene. J. biol. Chem., 152, 313-320.

Hickman, K. C. D., Harris, P. L., and Woodside, M. R. (1942). Interrelationship of vitamins $\mathrm{A}$ and E. Nature (Lond.), 150, 91-92.

Hopkins, F. G. (1906). The analyst and the medical man. Analyst, 31, 385-403.

Kimble, M. S. (1939). The photocolorimetric determination of vitamin $\mathbf{A}$ and carotene in human plasma. J. Lab. clin. Med., 24, 1055-1065.

McCollum, E. V., Simmonds, N., Becker, J. E., and Shipley, P. G. (1922). Studies on experimental rickets. XXI. An experimental demonstration of the existence of a vitamin which promotes calcium deposition. J. biol. Chem., 53, 293-312.

Moore, T. (1957). Vitamin A. Elsevier, Amsterdam. 